\title{
A THEORETICAL APPROACH TO THE TOURISM BUSINESSES MARKETING PLAN AND MANAGEMENT PROCESS
}

Assist. Prof. Yakup DURMAZ ${ }^{1}$ and Belma KULEOĞLU ${ }^{2}$

${ }^{1}$ Faculty of Economics Administrative and Social Sciences, Hasan Kalyoncu University, Havalimanı Yolu Üzeri 8. Km. Gaziantep,

Turkey. Tel: 90-342-211-8080. E-mail: yakup.durmaz@hku.edu.tr

${ }^{2}$ Gaziantep University. E-mail: belma974@hotmail.com

\section{Abstract}

The aim of this study was to identify the importance of marketing plan and management practices at tourism businesses. To perform of this aim, the literature was searched and some related studies which published at the marketing area were used. According to the results of the study, it was found that marketing plan and its management process is an important factor increasing both sales and profit rates at tourism busienesses.

Key Words: Marketing Plan, Marketing Management Process, Torusim Business

\section{Council for Innovative Research}

Peer Review Research Publishing System

Journal: JOURNAL OF SOCIAL SCIENCE RESEARCH

Vol 4, No 2

jssreditor.cir@gmail.com

www.jssronline.com/ojs 


\section{INTRODUCTION}

Businesses adapt to constantly changing conditions and to increase its market share in this way, but it is possible with the right planning. Effective planning and innovative strategies that determine the structure constitutes a more efficient and profitable businesses Businesses in tourism enterprises adopting this structure provide access to corporate goals and objectives strengths and weaknesses in the market who do not know how to follow a strategy that businesses would not know it. Marketing plans and management processes, provide both right place and time in a suitable time.

\section{TOURISM BUSINESSES MARKETING PLAN AND MANAGEMENT PROCESS}

Marketing planning is a sytematic process that covers marketing objectives and resources and also that provides plan development in this direction. Marketing Plan covers all activities to be implemented. Busisesses are to regulate the marketing plan, which is a written document in order to complete and control marketing activities (Pride ve Ferell, 2006:547).

Marketing planning process consists of 5 steps, these stages are given below (Kozak, 2008: 55-61):

\subsection{Situational Analysis}

As a business located in the tourist market, what are our strenghts and weaknesses? What are the factors that may be future opportunities or threats for us ? Questions to be answered effectively constitutes the phases of Situational Analysis.

\subsection{Determination of the mission and vision}

Defined as farsightedness, the vision reflects the imagine of future and also shows the thoughts how to be an organization. It can be explained that organizations that have the vision plan the future and define their position in the future. Mission is a term that shows what an organization wants to achieve in the long term and estimates what kind of organization should be in the future and also it is a concept that gives information about the reasons for the existence of a business (İslamoğlu,2010:40).

\subsection{Determination of the business strategy}

Businesses taking place in tourism industry endeavor to reach previously mentioned objectives, namely sales and profit levels with strategic business units. There are three strategies that a business can choose from in this issue. (Kozak, 2010:59):

\subsubsection{Intensive Growth Strategy}

Businesses will want to benefit more in the existing market in the future.. It is analyzed in 3 sections such as Market Penetration, Market Development, Product Development, (Uygur,2007:116-119):

- Market Penetration: Businesses are trying to improve their existing shares in the market. For example; They can change the amount of products that existing customers purchase in a given period . 'Stay 7 nights, pay 5 nights' is among this campaign for hotels.Or, they can try to reach new consumers by looking for new distribution channels in the current market.

- Merket development strategy: The business can try to increase sales by means of offering the existing goods into new market.

- Product Development Strategy: Business break into current market with new products.

\subsubsection{Integrative growth strategies}

Businesses grow in the current market in 3 ways.. Forwards and backwards, and also, they can increase sales and profits through horizontal integration (Uygur,2007:118).

Forward integration:It is the merging in the distribution channel with the following one.., such as a hotel's buying a travel agency.

Backward integration: In order to provide food and beverage, a hotel can purchase the business of its raw material suppliers.

Horizontal integration: It can be explained as the joining a business with the other in the same channel level, such as joining of a hotel with a different hotel.

\subsubsection{Diversified Growth Strategy}

One of the ways that businesses use is to put all the eggs in the same basket.Therefore, in order to take advantage of opportunities in different fields, they can change the products, the kind of facilities they serve, their operating areas and the group of customers that they sell product(İslamoğlu,2000:215). 


\subsection{Business Strategy Planning}

The plan that a business presents defines the workfield of business and purposes for every work field. More detailed plan should be made in every field. In the planning stage of pissing strategy, marketing, finance, production as well as human resources should be included.

\subsubsection{Strategic Marketing Plan Process}

"A company's strategic business plan determines types of business that the business will take place and the objectives for each strategic unit. After that, more detailed planning needs to be done for each strategic business unit"(Uygur,2007:119). The plan that businesses have used comprises of the steps below (Uygur,2007:119):

- Situational analysis

- Determination of business and marketing tools

- Strategy alternatives and choosing appropriate stragies

- Programming of the marketing mix

- Program coordination and integration

- Marketing plan

- Application

- Control

\subsubsection{Competitive Marketing Strategy}

Competitors are inevitable factor in the market that the businesses are taking place. Businesses need to determine how to behave against competitors. In this sense, competitive marketing strategies can be studied under 4 different headings(Uygur,2007:123-127):

1. Market Leading Competitive Strategies: It is being implemented by leading enterprises in the market The businesses whose market share is the highest are those which have the position of market leader. .These businesses determine the price and sales promotion strategies. the leader in the market follow 3 types of strategies which are given below.(Uygur,2007:123-124):

- The total market expansion strategies

- Market share expansion strategies

- Startegy to protect market share are.

2. Challenger Competitive Strategies:They take place at the rear of businesses which have the position of market leader and try to be süperior to leader and other powerful businesses by means of attacks. The purpose is to evaluate the innovation adoption and market opportunities (Uygur,2007:123-124).

3. Monitor Competitive Strategies: we see that the businesses adopting this strategy are more cautious and do not like to take risks, as well as they have a traditional structure. Therefore, the attack will not be suitable behaviour for them. These businesses prefer to follow the leader, provided that they keep the prices at a acceptable level, they do not like to raise the costs (Uygur,2007:123-124).

4. Competition in the market specialization strategies: Small scale enterprises emerge as the ones which implement this strategy. Those businesses that are experts in their fields do not complete with businesses that will be in a leading position in the market (Uygur,2007:123-124).

\subsection{Inspection and Correction}

functioning With the decision of appropriate marketing plan, the implementation process starts, at which point it is controlled whether the plan is correctly and if there is a fault, it is corrected immediately. (Uygur,2007:123-124).

\section{CONCLUSION}

Nowadays, as many people have traveled for different purposes, touirsm is becoming more important than ever. Moreover, as tourism has a significant potential in the world, , if the marketing strategy in this area is done correctly, the results will be very useful for both promoting the country and for contributing the country's economy. Therefore, to be successful in marketing, marketing plan and management process step should be created correctly and be applied correctly. 


\section{REFERENCES}

- Hazar, Atilla. (2010). Genel Turizm, Nobel Yayın Dağıtım.

- Altun, Şafak. (2008). İyi Fikir Her Zaman Kazandırır, Hayat Yayınları.

- Belet, Aydın. (2007). Müşteri Kazanma Teknikleri, Akis Kitap 21.yy Müşteri Çağı

- Beckwith, Harry. ( 2008). Görünmeyeni Satmak ( Çev. Ümit SENSOY), Optimist yayınları.

- Çağlar, İrfan-Kılıç, Sabiha. (2008). Pazarlama, Nobel Yayın Dağıtım 2.Baskı

- Yükselen ,Cemal. ( 2012). Pazarlama İlkeler - Yönetim - Örnek Olaylar, Detay Yayıncılık 10. Baskı.

- Çalık, Nuri. ( 2004). Pazarlama Yönetimi, Açıöğretim Üniversitesi Yayını No: 1478,2011, 9.Baskı.

- Hacıoğlu, Necdet. ( 2010). Turizm Pazarlaması, Nobel Yayın Dağıtım, 7.Baskı.

- Uygur, Selma. ( 2007). Turizm Pazarlaması, Nobel Yayın Dağıtım, Seri No:31.

- İslamoğlu, Ahmet Hamdi. ( 2000). Pazarlama Yönetimi, Beta Yayınları, 2.Baskı.

- Mucuk, İsmet. ( 1987). Pazarlama İlkeleri, Der Yayınları, 4.Baskı.

- Kozak, Nazmi. ( 2010). Turizm Pazarlaması, Detay Yayıncılık, 3.Baskı.

- Gel, Oğuz. (2007). Rekabetçi Satış Stratejileri, Sistem Yayıncılık.

- Odabaşı, Yavuz. ( 2000). Müşteri İlişkileri Yönetimi, Sistem Yayıncılık,8.baskı.

- Karahan, Kasım. ( 2006). Hizmet Pazarlaması, Beta Yayınları.

- Erol, Miktat. ( 2003). Turizm Pazarlaması, Ekin Yayınları.

- Kotler Philip and Keller KevinLina. ( 2006). Marketing Management, Prentice Hall, 12 Edition.

- Özdipçiner, Nuray Selma. ( 2010). Turizmde Elektronik Pazarlama, http://www.journalagent.com/z4/vi.asp?pdir=iuyd\&plng=tur\&un=IUYD-66376\&look4=

- Çuhadar Murat. ( 2001). Otel işletmelerinde bir pazarlama aracı olan internetin kullanımı, Isparta, Tez.

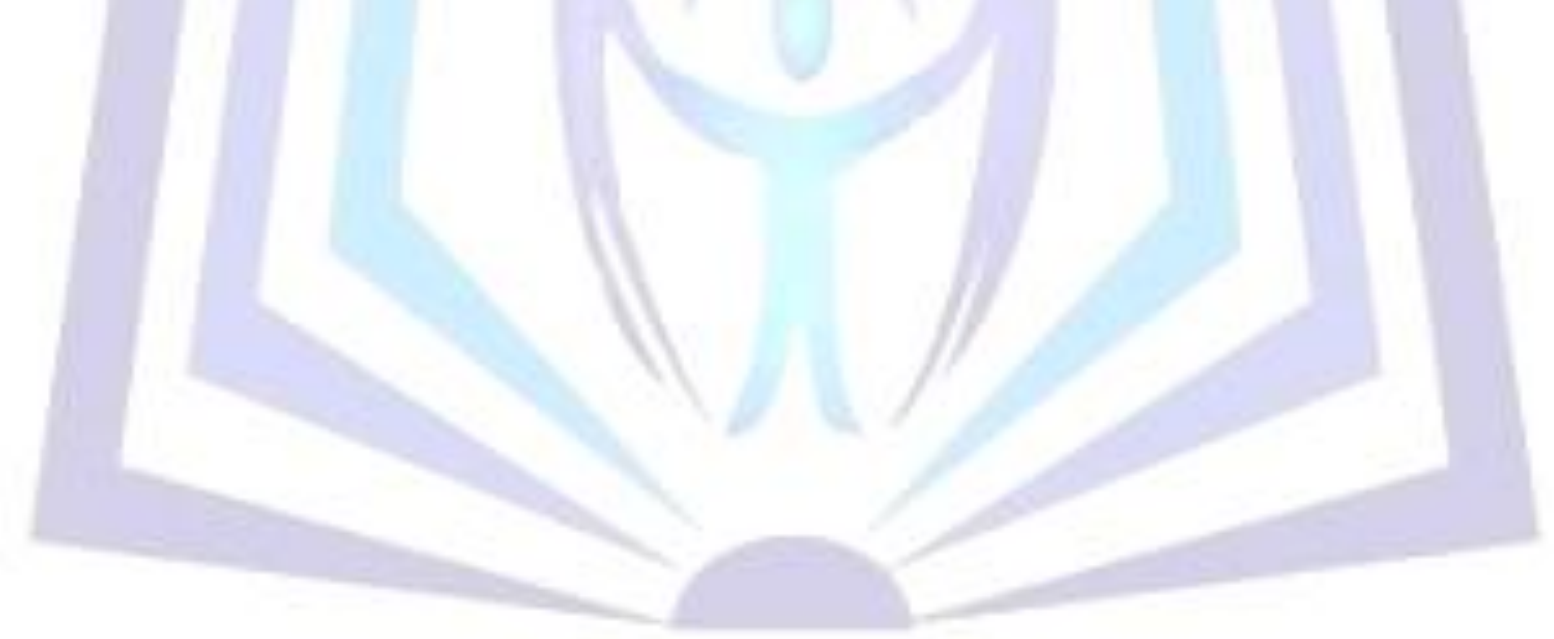

